\title{
A NEW INSIGHT INTO THE CLASSIFICATION OF SENNA SERIES APHYLLAE (LEGUMINOSAE)
}

\author{
Federico O. Robbiati ${ }^{1,2}$, Ana M. Anton', María J. Nores ${ }^{1,2,3}$ \& Renée H. Fortunato ${ }^{3,4,5}$
}

\begin{abstract}
${ }^{1}$ Instituto Multidisciplinario de Biología Vegetal, CONICET-Universidad Nacional de Córdoba, Casilla de Correo 495, 5000 Córdoba, Argentina; federobbiati@gmail.com (author for correspondence).

${ }^{2}$ Facultad de Ciencias Exactas, Físicas y Naturales, Universidad Nacional de Córdoba, Vélez Sarsfield 299, 5000 Córdoba, Argentina.

${ }^{3}$ Consejo Nacional de Investigaciones Cientificas y Técnicas (CONICET).

${ }^{4}$ Instituto de Recursos Biológicos, CIRN-INTA-CONICET, Nicolás Repetto y de Los Reseros $s / n^{\circ}, 1686$ Hurlingham, Buenos Aires, Argentina.

${ }^{5}$ Facultad de Agronomía y Ciencias Agroalimentarias, Universidad de Morón, Cabildo 134, $6^{\circ}$ piso, 1708 Morón, Buenos Aires, Argentina.
\end{abstract}

\begin{abstract}
Robbiati, F. O.; A. M. Anton, M. J. Nores \& R. H. Fortunato. 2019. A new insight into the classification of Senna Series Aphyllae (Leguminosae). Darwiniana, nueva serie 7(1): 57-64.

A new classification in Senna Series Aphyllae based on distribution, morphology and phylogenetic evidences is proposed to contribute to a better comprehension of the series. Here, Senna aphylla var. divaricata and S. aphylla var. pendula are transferred to S. pachyrrhiza. Furthermore, $S$. rigidicaulis is considered a synonym of $S$. crassiramea, and a lectotype is designated for Cassia aphylla var. divaricata and C. crassiramea. Then, Series Aphyllae is composed by six species and two varieties.
\end{abstract}

Keywords. Aphyllae; nomenclatural changes; taxonomy.

Resumen. Robbiati, F. O.; A. M. Anton, M. J. Nores \& R. H. Fortunato. 2019. Una nueva perspectiva sobre la clasificación de Senna Series Aphyllae (Leguminosae). Darwiniana, nueva serie 7(1): 57-64.

Se propone una nueva clasificación de Senna Serie Aphyllae (Leguminosae) basada en distribución, morfología y evidencias filogenéticas para contribuir a una mejor comprensión de la serie. Aquí, Senna aphylla var. divaricata y S. aphylla var. pendula son transferidas a S. pachyrrhiza. Además, se considera que $S$. rigidicaulis es un sinónimo de $S$. crassiramea y se designa lectotipo para Cassia aphylla var. divaricata y C. crassiramea. Entonces, la Serie Aphyllae está compuesta por seis especies y dos variedades.

Palabras clave. Aphyllae; cambios nomenclaturales; taxonomía. 


\section{INTRODUCTION}

Series Aphyllae Benth. belongs to the genus Senna Mill. (Leguminosae) and occurs in arid and semi-arid zones of southern Bolivia, southern-central Paraguay and is widely distributed from northwestern and central Argentina to the northern coasts of Patagonia. Its distribution area in Argentina involves four extensive biogeographic provinces, Chaco, Monte, Prepuna and Patagonia (Cabrera \& Willink, 1980) which, in general, have been poorly studied. This series comprises xeromorphic shrubs and subshrubs, commonly known as "pichanas", with deeply penetrating woody roots, leaves reduced to minute triangular or sublobate scales, and junciform, green and photosynthetic stems.

Through time Series Aphyllae has been subject to much reorganization since Burkart (1946) first revised the section (sub. nom. Cassia Series Aphyllae) and afterward the argentinean representatives (Burkart, 1952). On this base, Bravo (1978a, 1978b, 1982) produced an exhaustive revision of the group taking into account characteristics of the habit, floral pieces pubescence, and angle divergence of branches. As a result, she recognized 11 species, two subspecies and four varieties. Irwin \& Barneby (1982), focusing on reproductive characters, transferred Series Aphyllae to the genus Senna, a criterion widely accepted, even though specific and varietal delimitation remained unclear in several members of the series.

More recently, we studied this series with different approaches. Based on phenetic and seed protein profiles we reinterpreted Aphyllae's taxonomy proposing seven species and three varieties (Robbiati et al., 2013, 2014a, 2014b). Afterwards, by means of statistical analyses of climatic and morphological data, and geographical distribution, we tried to understand the patterns of morphological variation among individuals to clarify the taxonomic delimitation of the entities involved in the series (Robbiati et al., 2017a). Furthermore, we investigated the evolutionary history of Aphyllae in a molecular phylogenetic framework (Robbiati et al., 2017b).
In this context, we reviewed our thinking about the classification of series Aphyllae, concluding that a new insight is needed to guarantee a better comprehension of it.

\section{MATERIALS AND METHODS}

We studied material collected in southern, central and northern Argentina and southern Bolivia, between the years 2010-2017, as well as specimens deposited in the following herbaria: BAB, CORD, CTES, LIL, MA, LP, LPB, MCNS, SI, SRFA and Z (Thiers, 2019).

\section{TAXONOMY}

Senna ser. Aphyllae (Benth.) H.S. Irwin \& Barneby, Mem. New York Bot. Gard. 35: 567. 1982. Cassia ser. Aphyllae Benth., Trans. Linn. Soc. London 27: 542. 1871. TYPE SPECIES: Cassia aphylla Cav., lectotype designated by H.S. Irwin \& Barneby, Mem. New York Bot. Gard. 35: 567. 1982.

Senna acanthoclada (Griseb.) H.S. Irwin \& Barneby, Mem. New York Bot. Gard. 35: 570. 1982. Cassia acanthoclada Griseb., Abh. Königl. Ges. Wiss. Göttingen 24: 116. 1879. TYPE: Argentina, Catamarca, "San Miguel au der Saline", XI-1872, P. G. Lorentz \& G. Hieronymus 481 (lectotype GOET cb 008876!, designated by F. Robbiati et al., Phytotaxa 162: 84. 2014a; isolectotypes CORD cb 00005844!, F cb 0057472F!, F cb 0BN001642!, SI cb 001917!). Fig. 1A.

Distribution and habitat. Western and central Argentina, growing in salty soils in the provinces of Catamarca, Córdoba, La Rioja, San Juan, and San Luis.

Observations. When we selected the lectotype among the syntypes of $S$. acanthoclada Griseb. (Robbiati et al., Phytotaxa 162: 84. 2014a), we confused the collection data of two specimens: $G$. Hieronymus 443 and P. G. Lorentz \& G. Hieronymus 481. This conflict desserves a rectifying comment and is clarified above. 
Senna aphylla (Cav.) H.S. Irwin \& Barneby, Mem. New York Bot. Gard. 35: 570. 1982. Cassia aphylla Cav., Icon. 6: 41, pl. 561. 1801. TYPE: Argentina, Mendoza, Capital, Cordillera del Pocillo de Mendoza a Chile, Buenos Aires, L. Née s. n. (holotype MA cb 475495!). Fig. 1B.

Cassia aphylla var. rigida Hieron., Bol. Acad. Nac. Ci. 4: 24. 1881. TYPE: Argentina, San Juan, Pocito, Pedregal del Pocito, XII1875, S. Echegaray s. n. (holotype CORD cb 00003183 !).

Cassia aphylla var. trichosepala Chodat \& Wilczek, Bull. Herb. Boissier, sér. 2, 2: 475. 1902. Cassia trichosepala (Chodat \& Wilczek) L. Bravo, Darwiniana 21: 373. 1978. Senna trichosepala (Chodat \& Wilczek) H.S. Irwin \& Barneby, Mem. New York Bot. Gard. 35: 570. 1982. TYPE: Argentina, Mendoza, San Rafael, "SaintRaphaël, 800 m”, I-II-1897, E. Wilczek 93 (holotype US).

Cassia aphylla var. virgata Burkart, Fl. Prov. Bs As, Colecc. Ci. Inst. Nac. Tecnol. Agropecu. 4(3a): 451. 1967. TYPE: Argentina, Buenos Aires, A. Alsina, Laguna de Chasilauquen, 17-XI-1962, A. L. Cabrera \& H. A. Fabris 14806 (holotype SI cb 001919!; isotype LP cb 011233 !).

Cassia fabrisii L. Bravo, Darwiniana 21: 377. 1978. Senna fabrisii (L. Bravo) H.S. Irwin \& Barneby, Mem. New York Bot. Gard. 35: 570. 1982. TYPE: Argentina, San Juan, Iglesia, $10 \mathrm{~km}$ de Pismanta hacia Rodeo, 15-I-1976, R. A. Palacios \& L. D. Bravo 593 (holotype SI cb 001927!; isotype SI cb 001928!).

Cassia rigida var. inermis L. Bravo, Darwiniana 21: 373. 1978. Senna rigida var. inermis (L. Bravo) L. Bravo, Brittonia 38: 270. 1986. TYPE: Argentina, La Rioja, $32 \mathrm{~km}$ al Sur de Tinogasta, 18-I-1976, R. A. Palacios 629 (holotype SI cb 001938!; isotype SI cb 001939 !).

Distribution and habitat. Western and central Argentina, growing in sandy and rocky soils in Catamarca, La Rioja, Mendoza, Salta, San Juan, and San Luis provinces.
Senna crassiramea (Benth.) H.S. Irwin \& Barneby, Mem. New York Bot. Gard. 35: 569. 1982. Cassia crassiramea Benth., Hooker's Icon. Pl. 11: 50, pl. 1063. 1870. TYPE: South America [Argentina]. Salta: San Vicente, dry hills, at $6000 \mathrm{ft} .$, II-1864, R. Pearce s. $n$. (lectotype here designated: K cb 000555433!). Fig. 1C.

Cassia rigidicaulis Burkart ex L. Bravo, Darwiniana 21: 364. 1978. Senna rigidicaulis (Burkart ex L. Bravo) H.S. Irwin \& Barneby, Mem. New York Bot. Gard. 35: 569. 1982. TYPE: Argentina, Salta, Molinos, Seclantas Adentro, 25-XII1972, R. Kiesling 169 (holotype SI cb 001941!). Syn. nov.

Distribution and habitat. Southern Bolivia and northwestern Argentina (Catamarca, Jujuy, La Rioja, Salta, and Tucumán provinces), growing in mountainous slopes on rocky soils.

Observations. When describing Cassia crassiramea, Bentham cited three syntypes, one from Bolivia, Weddell s.n., and another two from Argentina: "Andes of Salta 6000-8000 ft., and dry hills of SanVicente at $6000 \mathrm{ft}$.", Pearce s.n. The last two are on the same sheet at K (as K cb 000555434! and $\mathrm{K}$ cb 000555433 ! respectively). We designed the latter as lectotype of the species, since it fully agrees with the protologue of the species.

Misapplied names. Cassia rigida (Hieron.) Burkart, sensu Burkart, Legum. Argent. (ed. 2): 168. 1952. Senna rigida auct. non (Hieron.) H.S. Irwin \& Barneby. Mem. New York Bot. Gard. 35: 570. 1982.

Senna nudicaulis (Burkart) H.S. Irwin \& Barneby, Mem. New York Bot. Gard. 35: 570. 1982. Cassia nudicaulis Burkart, Bol. Soc. Argent. Bot. 6: 226. 1957. TYPE: Argentina, Neuquén, Pehuenches/Añelo, Sierra Auca Mahuida, XI-1953, H. A. Fabris 823 (holotype SI cb 001932!). Fig. 1A.

Distribution and habitat. This species is a rare endemic taxon distributed in La Payunia district of the Patagonian biogeographic province 
(Mendoza and Neuquén), growing in rocky mountains and dry soils. In addition to the type specimen, only three specimens have been collected in Mendoza, Argentina (Troiani \& Steibel, 2001).

Senna pachyrrhiza (L. Bravo) H.S. Irwin \& Barneby, Mem. New York Bot. Gard. 35: 570. 1982. Cassia pachyrriza L. Bravo, Darwiniana 21: 380. 1978. TYPE: Argentina, Catamarca, Santa María, Campos del Arenal, Ruta 40, km 935, 21-I-1976, R. A. Palacios 648 (holotype SI cb 001935!).

var. pachyrrhiza. Fig. 1D.

Cassia aphylla var. divaricata Hieron., Bol. Acad. Nac. Ci. 3: 346. 1881. Cassia aphylla subsp. divaricata (Hieron.) L. Bravo, Darwiniana 21: 386. 1978. Senna aphylla subsp. divaricata (Hieron.) L. Bravo, Brittonia 38: 270. 1986. TYPE: Argentina, Buenos Aires, Patagones, Carmen de Patagones, Patagonia, 17-XI1874, C. Berg s. n. (lectotype here designated, CORD cb 00003174!). Syn. nov.

Distribution and habitat. Western and central Argentina, growing in sandy soils in Buenos Aires, Chubut, Catamarca, Córdoba, La Pampa, La Rioja, Mendoza, Neuquén, Río Negro, and San Juan provinces.

Observations. When describing Cassia aphylla var. divaricata, Hieronymus mentioned several specimens. Of these, we were able to examine the specimen collected by Berg near Carmen de Patagones; it is here designed as lectotype of the species, since it fully agrees with the protologue of the species.

Misapplied names. Senna aphylla var. divaricata sensu Robbiati \& Fortunato, Bot. J. Linn. Soc. 455. 2017.

var. pendula (Robbiati \& Fortunato) Robbiati \& Fortunato, comb. nov. Senna aphylla var. pendula Robbiati \& Fortunato, Phytotaxa 162: 86. 2014. TYPE: Argentina, Córdoba,
Punilla, sobre ruta nacional 38, Capilla del Monte en dirección al Zapato, $30^{\circ} 50^{\prime} \mathrm{S} 64^{\circ}$ $32^{\prime} \mathrm{W}, 12-\mathrm{IV}-2010, R$. H. Fortunato et al. 9622 (holotype BAB cb 00004708!; isotype BAB cb 00004732!). Fig. 1D.

Distribution and habitat. Central Argentina, Catamarca, Córdoba, La Pampa, La Rioja, Mendoza, Río Negro, Salta, San Juan, San Luis, Santiago del Estero, and Tucumán, growing in sandy and clay soils in the Monte and Chaco biogeographic provinces (Chaqueño Serrano district).

Misapplied names. Cassia aphylla sensu Burkart, Legum. Argent. (ed. 2): 168. 1952 (fig. 29, b. c.); Cassia aphylla sensu Burkart, Fl. Prov. Buenos Aires, Colecc. Ci. Inst. Nac. Tecnol. Agropecu. 4(3a): 451: 1967; Cassia aphylla sensu Bravo, Darwiniana 21:383. 1978; Cassia aphylla sensu Bravo, Fl. Patagónica, Colecc. Ci. Inst. Nac. Tecnol. Agropecu. 8(4b): 209. 1984.

Senna spiniflora (Burkart) H.S. Irwin \& Barneby, Mem. New York Bot. Gar. 35: 569. 1982. Cassia spiniflora Burkart, Darwiniana 7: 235. f. 5. 1946. TYPE: Paraguay, Entre Toba Quemado y Margariños, Sector Pilcomayo, IX-1938, T. Rojas 8269 (holotype SI cb 001942!; isotype SI cb 001943!). Fig. 1C.

Cassia aphylla var. robusta Burkart, Darwiniana 7: 237. 1946. Cassia rigida var. robusta (Burkart) Burkart, Legum. Argent. (ed. 2): 544. 1952. Cassia chacoënsis L. Bravo, Darwiniana 21: 359. 1978. Senna chacoënsis (L. Bravo) H.S. Irwin \& Barneby, Mem. New York Bot. Gard. 35: 569. 1982. TYPE: Argentina, Santiago del Estero, Gral. Taboada, Añatuya, 27-I-1944, A. Soriano 571 (holotype SI cb 001940!).

Distribution and habitat. Southern-central Paraguay and northern-central Argentina, in clay soils in the provinces of Chaco, Córdoba, Formosa, Salta, Santa Fe, Santiago del Estero, and Tucumán. 
F. O. ROBBIATI ET AL. A new classification of Senna Series Aphyllae

A

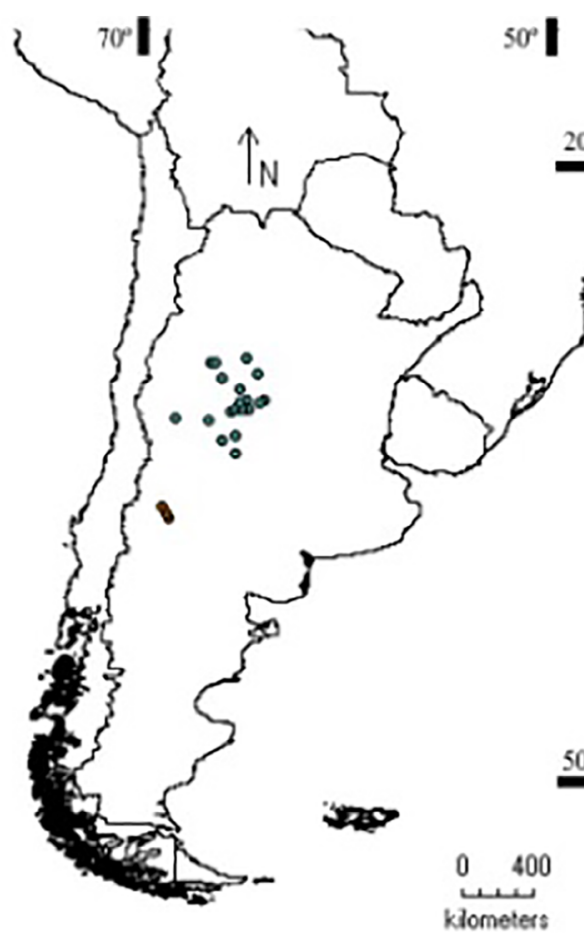

C

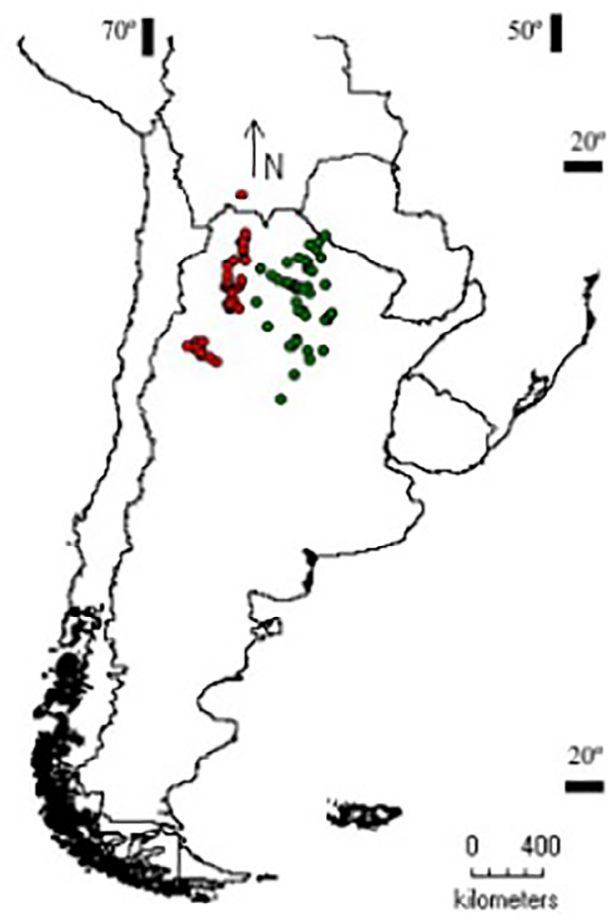

B

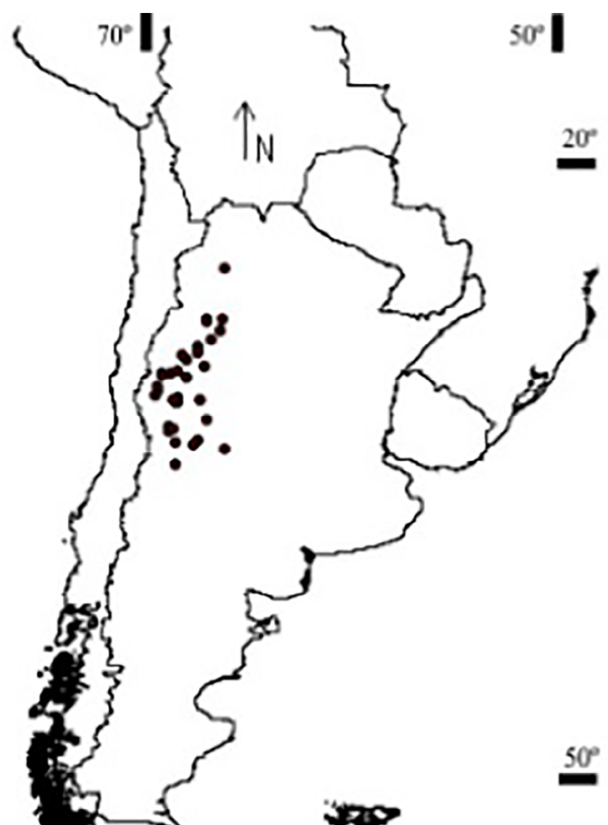

$50^{\circ}$

D

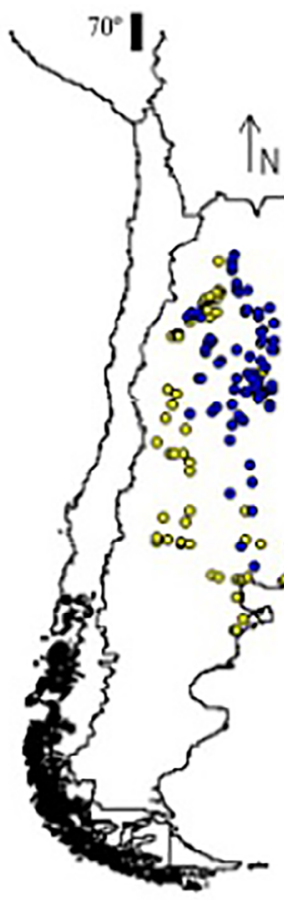

$20^{\circ}$

$20^{\circ}$
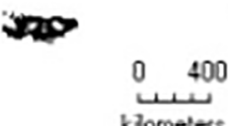

Fig. 1. Geographic distribution of species of Senna Series Aphyllae. Geographic coordinates of herbarium specimens were obtained from Google Earth. Localities were mapped using DIVA-GIS (Hijmans et al., 2012). A, S. acanthoclada (light blue), S. nudicaulis (brown). B, S. aphylla. C, S. crassiramea (red), S. spiniflora (green). D, S. pachyrrhiza var. pachyrrhiza (yellow), S. pachyrrhiza var. pendula (blue). Color version at http://www.ojs.darwin.edu.ar/index.php/ darwiniana/article/view/844/1154 


\section{Key to the species of Senna Series Aphyllae}

1. Diffuse, prostrate or suberect subshrubs, up to $0.4 \mathrm{~m}$ tall, intricately branched, the stems silky-puberulent; the ultimate branchlets less than $2 \mathrm{~cm}$ long 2

1. Mostly erect shrubs and subshrubs $0.4-2.5 \mathrm{~m}$ tall, less often smaller but if so, the stems glabrous; ultimate branchlets more than $2 \mathrm{~cm}$ long 3

2(1). Primary stems 20-50(-70) cm, prostrate, repeatedly and intricately branched; racemes corymbiform, mostly 3-5-flowered. Monte biogeographic province and Chaqueño Serrano district in Chaco biogeographic province S. acanthoclada

2. Primary stems 10-20 cm, suberect, little branched; racemes 1-flowered. Endemic from la Payunia district in the Patagonian biogeographic province S. nudicaulis

3(1). Branchlets mostly spreading at a right angle, stiff and spine-tipped. Chaco biogeographic province S. spiniflora

3. Branchlets either less abruptly divaricate or, if not so, the whole axis conspicuously zigzag .. 4

4(3). Branchlets stout, fastigiate, ascending and narrower at both ends, 3-9 mm diam. or, if less, finely setaceous at the base. Prepuna biogeographic province S. crassiramea

4. Branchlets neither fastigiate nor narrowed toward point of origin, 1-5 mm diam., always glabrous 5 5(4). Branchlets erect; young branches, bracts, peduncles and pedicels pubescent or, if glabrous, then the calyx silkysetose. Monte biogeographic province S. aphylla

5. Branchlets pendulous or conspicuously zigzag; plants wholly glabrous or the pedicels and calyx rarely puberulent ....... 6 6(5). Primary branches erect-ascending to decumbent, conspicuously zigzag, the ultimate branchlets inermis to spinulose; shrubs, subshrubs or dwarf subshrubs. Monte and Patagonian provinces S. pachyrriza var. pachyrrhiza 6. Primary branches erect-ascending, the ultimate branchlets inermis and pendulous; shrubs and subshrubs. Chaco and Monte biogeographic provinces S. pachyrrhiza var. pendula

\section{DISCUSSION AND CONCLUSIONS}

One case to deal with is the identity of Senna aphylla (Cav.) H.S. Irwin \& Barneby and its varieties [var. aphylla, var. pendula Robbiati \& Fortunato and var. divaricata (Hieron.) Robbiati \& Fortunato] in relation with $S$. pachyrrhiza (L. Bravo) H.S. Irwin \& Barneby, whose high morphological variation makes specific and varietal delimitation problematic.

Senna aphylla var. aphylla is differentiated by the presence of straight and armed branches and a glabrous to densely pubescent calyx; its distribution area comprises mainly the western region of Argentina in the Monte biogeographic province. Senna aphylla var. pendula is distinguished by the pendulous unarmed branches and occurs in the central region of the Monte and Chaco provinces, expanding to the east. Senna aphylla var. divaricata is characterized by the decumbent and flexuous unarmed branches and inhabits the central-southern region of the Monte province, extending to Patagonia. The calyx is mainly glabrous in the last two varieties.
Senna pachyrrhiza is morphologically similar to $S$. aphylla var. divaricata, both sharing flexuous branchlets and decumbent to pseudodecumbent stems and their preference for salty and sandy soils (Robbiati et al., 2017a). It has a peculiar geographical distribution, since it is an endemism of the "Campo del Arenal", an extensive plain of about $2000 \mathrm{~km}^{2}$, delimited by a group of mountains belonging to the "Sierras Pampeanas" system (Nores, 1986) in the Monte province.

In the phylogenetic hypothesis proposed by Robbiati et al. (2017b), S. aphylla s. 1. is supported as polyphyletic, being $S$. aphylla var. aphylla an independent single evolutionary unit in one clade while the other varieties, together with $S$. pachyrrhiza, integrate another one, with poor resolution among taxa. These results are consistent with morphometric analyses that revealed a clear differentiation of $S$. aphylla var. aphylla from the rest of the entities; instead, S. aphylla var. divaricata and $S$. 
aphylla var. pendula are poorly differentiated, and S. pachyrrhiza could not be distinguished from $S$. aphylla var. divaricata (Robbiati et al., 2017a). Interestingly enough, we have observed in the field some characters used to differentiate Senna pachyrrhiza -such as pseudo-decumbent stems, terminal spinose branchlets and sand dwarf habit- in individuals of $S$. aphylla var. divaricata at high elevation in the steppe, in the Patagonian province; in addition, plant height in the series is correlated with elevation (Robbiati et al., 2017a). Furthermore, the overlapping distribution of all these taxa in the Monte province plus the ecological niche modeling, have shown several areas of contact and a large overlap in zones of suitable conditions (Robbiati et al., 2017a). Then, based on morphology, distribution and phylogenetic evidence, we propose to transfer from Senna aphylla the varieties divaricata and pendula to S. pachyrrhiza.

The second case involves Senna crassiramea (Benth.) H.S. Irwin \& Barneby and $S$. rigidicaulis (Burkart ex L. Bravo) H.S. Irwin \& Barneby. Both have fastigiated and thickened branches -differing only in the degree of thickening and fastigiation-, with the presence of several intermediate individual. Both entities share, in part, an overlapping distribution in the Prepuna province.

It is interesting to note that in the multivariate analysis (Robbiati et al., 2017a), Senna crassiramea and S. rigidicaulis appear grouped and in the phylogenetic reconstruction they appear as sister taxa but with a low support (Robbiati et al., 2017b). All these facts have led us to propose their synonymy.

According this evaluation, we propose here that Series Aphyllae is composed by six species and two varieties as follows: Senna acanthoclada (Griseb.) H.S. Irwin \& Barneby, S. aphylla (Cav.) H.S. Irwin \& Barneby, $S$. crassiramea (Benth.) H.S. Irwin \& Barneby, $S$. nudicaulis (Burkart) H.S. Irwin \& Barneby, $S$. pachyrrhiza (L. Bravo) H.S. Irwin \& Barneby var. pachyrrhiza, S. pachyrrhiza var. pendula (Robbiati \& Fortunato) Robbiati \& Fortunato comb. nov., and S. spiniflora (Burkart) H.S. Irwin \& Barneby (Fig. 1).

\section{ACKNOWLEDGEMENTS}

We are grateful to the curators of the herbaria cited under Materials and methods. This study was supported by the Consejo Nacional de Investigaciones Científicas y Técnicas (CONICET; Grants PIP 112200801-00323 and PIP112-201101-00250), FONCyT (PICT 2014-1095), by Instituto Nacional de Tecnología Agropecuaria (INTA) and SECyT-UNC (32720160200161CB).

\section{BIBLIOGRAPHY}

Bravo, L. D. 1978a. El género Cassia en la Argentina, I. Serie Aphyllae. Darwiniana 21: 343-391. https://www. jstor.org/stable/23215597

Bravo, L. D. 1978b. Estudio comparativo de las plántulas de las subespecies de Cassia aphylla Cav. Darwiniana 21: 393-399. https://www.jstor.org/stable/23215598

Bravo, L. D. 1982. Estudio de las semillas del género Cassia Serie Aphyllae Darwiniana 24: 455-468. https:// www.jstor.org/stable/23216525

Burkart, A. 1946. Leguminosas nuevas o críticas. Darwiniana 7: 216-239. https://www.jstor.org/stable/23211628

Burkart, A. 1952. Las leguminosas argentinas silvestres y cultivadas, $2^{\mathrm{a}}$. edición. Buenos Aires: Acme.

Cabrera, A. L. \& A. Willink. 1980. Biogeografía de América Latina, $2^{a}$. edición. Serie de Biología, Monografía 13. Washington D.C.: Secretaría General de la OEA. (Publ. orig. 1973).

Hijmans, R. J.; L. Guarino \& P. Mathur. 2012. DIVA-GIS. Version 7.5. A geographic information system for the analysis of species distribution data, http://www.divagis.org/

Irwin, H. S. \& R. C. Barneby. 1982. The American Cassinae: A synoptical revision of Leguminosae, tribe Cassiae subtribe Cassiinae in the New World. Memoirs of the New York Botanical Garden 35: 567-570.

Nores, M. 1986. Diez nuevas subespecies de aves provenientes de islas ecológicas argentinas. El Hornero 12: 262-273.

Robbiati, F. O.; A. Lamarque, A. M. Anton \& R. H. Fortunato. 2013. Phenetic analysis of the complex Senna fabrisii-S. trichosepala (Leguminosae, Caesalpinioideae, Aphyllae) based on morphological characters and seed protein electrophoretic profiles. Phytotaxa 145: 1-14. DOI: 10.11646/phytotaxa.145.1.1 
Robbiati, F. O.; L. Ariza Espinar, A. M. Anton \& R. H. Fortunato. 2014a. Lectotypification, synonymy, and a new name in Senna Series Aphyllae (Leguminosae: Caesalpinioideae). Phytotaxa 162: 84-90. DOI: 10.11646/phytotaxa.162.2.2

Robbiati, F. O.; A. M. Anton \& R. H. Fortunato. 2014b. A new synonym in Senna, Series Aphyllae (Leguminosae, Caesalpinioideae). Systematic Botany 39: 1120-1126. DOI: $10.1600 / 036364414 X 683840$

Robbiati, F. O.; L. D. Amarilla, A. M. Anton \& R. H. Fortunato. 2017a. Phenotypic variation in arid and semiarid zones of southern South American: the case of Senna Series Aphyllae (Fabaceae, Caesalpinioideae). Botanical Journal of the Linnean Society 183:454-473. DOI: 10.1093/botlinnean/bow012
Robbiati, F. O.; A. M. Anton, B. Marazzi, M. Vásquez-Cruz \& R. H. Fortunato. 2017b. The evolutionary history of Senna ser. Aphyllae (Leguminosae-Caesalpinioideae), an endemic clade of southern South America. Plant Systematics and Evolution 303: 1351-1366. DOI: 10.1007/s00606-017-1450-7

Thiers, B. 2019 [continuously updated]. Index Herbariorum: a global directory of public herbaria and associated staff. New York Botanical Garden's Virtual Herbarium. http://sweetgum.nybg.org/ih (last accessed June 2019).

Troiani, H. O. \& P. E. Steibel. 2001. Caracteres carpológicos, seminales y distribución de Senna nudicaulis (Leguminosae). Boletín de la Sociedad Argentina de Botánica 36: 305-307. https://botanicaargentina.com.ar/ wp-content/uploads/2018/06/305-307.pdf 